\title{
Critical political ecology and the seductions of posthumanism
}

\author{
Fayaz Chagani ${ }^{1}$ \\ York University, Canada
}

\begin{abstract}
"Posthumanist" theories have become increasingly popular among scholars in political ecology and other fields in the human sciences. The hope is that they will improve our grasp of relations between humans and various nonhumans and, in the process, offer the means to recompose the "social" and the "natural" domains. In this paper, I assess the merits of posthumanisms for critical scholarship. Looking specifically at the work of Bruno Latour (including his latest book, An inquiry into modes of existence) and Donna Haraway, I argue that posthumanist thinking offers not only analytical but normative advantages over conventional and even Marxian approaches. But these newer frameworks contain their own ethico-political limitations and, to the extent that they are useful for addressing conditions of injustice, they continue to depend upon conceptual resources from their precursors. For this reason, a critical political ecology would best be served by preserving a tension between humanist and posthumanist methods.
\end{abstract}

Keywords: posthumanism, critical theory, political ecology, human-nonhuman relations, Bruno Latour, Donna Haraway

\section{Résumé}

Les théories "posthumaniste» sont devenus de plus en plus populaire parmi les spécialistes de l'écologie politique et d'autres domaines des sciences humaines. L'espoir est qu'ils amélioreront notre compréhension des relations différents entre les humains et non-humains. Et, dans le processus, offrir les moyens de recomposer les domaines «social» et «naturels». Dans cet article, je évaluer les avantages de posthumanismes pour érudition critique. Je suis particulièrement intéressé par les travaux de Bruno Latour (y compris son dernier livre, Une enquête sur les modes d'existence) et Donna Haraway. Je soutiens que la pensée posthumaniste offre non seulement des avantages analytiques mais normatifs par rapport aux approches classiques et même marxistes. Mais ces cadres nouveaux contiennent leurs propres limites éthico-politiques et, dans la mesure où ils sont utiles pour traiter des conditions de l'injustice, ils continuent à s'appuyer sur les ressources conceptuelles de leurs précurseurs. Pour cette raison, une «critical» écologie politique serait mieux servi en conservant une tension entre l'approche humaniste et posthumaniste.

Mots-clés: post-humanisme, la théorie critique, l'écologie politique, les relations homme-non humain, Bruno Latour, Donna Haraway

\section{Resumen}

Teorías "posthumanista" se han convertido cada vez más popular entre académicos en la ecología política y otros campos de las ciencias humanas. Se espera que se mejoren nuestra comprensión de las relaciones entre los humanos y los diversos no-humanos, y través del proceso, se ofrezcan los medios para recomponer los dominios "social" y "naturales". En este artículo, evalúo los méritos de posthumanismo para los estudios críticos. Examinando específicamente la obra de Bruno Latour (incluyendo su último libro, Investigacion sobre los modos de existencia) y Donna Haraway, sostengo que el pensamiento posthumanista no sólo ofrece ventajas analíticas, sino que también ventajas normativas sobre los enfoques convencionales, e incluso los del marxismo. Sin embargo estos nuevos marcos encarnan sus propias limitaciones ético-políticas y, en la medida en que son útiles para hacer frente a las condiciones de injusticia, siguen dependiendo de los recursos conceptuales de sus precursores. Por esta motivo, una ecología política crítica sería mejor servido con la preservación de una tensión entre métodos humanistas y posthumanista.

Palabras clave: posthumanismo, teoría crítica, la ecología política, las relaciones humano y no-humano, Bruno Latour, Donna Haraway

\footnotetext{
${ }^{1}$ Fayaz Chagani, Ph.D. candidate, Graduate Program in Social and Political Thought, York University, Toronto, Ontario, Canada. Email: chagani "at" yorku.ca. I would like to thank Catriona Sandilands for her mentorship and her generosity of spirit. Thanks also to Peter Vandergeest, Simon Batterbury, and the anonymous reviewers for their great help in improving this paper and making it publishable. Whatever flaws remain in this version are my responsibility alone. Thanks to Jessica Vorstermans for producing the Spanish abstract. Finally, my deepest gratitude to Andrea Sellinger without whom even an initial draft would not have been possible.
} 


\section{Introduction}

Despite its methodological diversity, research in political ecology is united by a concern to bring into conversation the natural and the social sciences in order to better understand relations between human beings and the biophysical world. Crucial to the work of political ecologists, in this regard, is the overcoming of the nature-society dualism that has been a constitutive component of Euro-American modernity. To this end, a variety of "posthumanist" or "more-than-human" theories have been appropriated by scholars working in this and in related fields (e.g., Braun and Castree 1998, 2001; Hinchcliffe 2005; Neumann 2005; Robbins 2012; Swyngedouw 1999; Whatmore 2002; White and Wilbert 2009). The purpose of this essay is to explore the effects of this appropriation. What, can we say, are the potential benefits and costs-particularly from the perspective of a critical approach to inter-human and human-nonhuman relations - of a posthumanist framework? How can the "human" sciences take "matter" seriously and avoid the pitfalls presented by such a negotiation?

My approach will be, first of all, to offer a brief overview of posthumanism. I will then turn to the thinking of Bruno Latour, perhaps the most (in)famous posthumanist, to outline how his version of "actornetwork theory" (hereafter ANT) offers a much-needed correction to much of the scholarship being produced in the human sciences. I will propose, unlike many other critics, that ANT does not in fact lack a normative dimension. It is nevertheless troubled by contradictions and lacunae and is therefore unable, in certain ways, to advance its own aspirations. Latour's most recent book, An inquiry into modes of existence (2013), presents a compelling new research program which compensates for many of the deficiencies of ANT. And yet problems remain, notably in a narrow conception of experience and an enduring allergic reaction to "critique." Some of the limitations of Latour's project are remedied by the work of Donna Haraway, the other theorist under consideration here. In the end, however, Haraway's theoretical arsenal is no more capable than Latour's of providing us with - and might in fact take from us - the resources necessary to ground our ethico-political decisions. Because of this, posthumanist methods must continue to be supplemented by and kept in tension with more conventional, humanist ones. The latter cannot be abandoned if we wish to make appeals for justice on behalf of human and nonhuman animals. ${ }^{2}$

\section{Beyond the human}

Posthumanism is a recent arrival to the academic scene. Though its intellectual origins are likely traceable to the "antihumanism" of Louis Althusser and to declarations made about the "death of man" by philosophers like Michel Foucault, the term itself acquired widespread usage in the social sciences and humanities only in the mid-1990s (Wolfe 2010). Since that time, many different and even competing definitions and forms have been produced. To make matters worse, relatively few posthumanists accept the term as a description for their work or their positions, and some even reject it altogether (e.g., Haraway 2008: 17). Still, it is possible to identify two features of posthumanism that extend across its various forms. At the most basic level, posthumanist theory is characterized by its radical ontological positions or, to be more specific, by the challenge it poses to the tidy demarcation between the human and the nonhuman worlds. In place of this usual binary, posthumanists highlight the complex ways in which humans are intertwined with and, in fact, inseparable from nonhumans. And in this case "nonhuman" signifies a number of "things" from the material to the immaterial and the organic to the inorganic. To some theorists, this entanglement and blurring of boundaries signals the arrival of a new era (hence the prefix "post"). But for others, this sort of pronouncement ignores that the boundaries have always been blurred and that there have never been, nor will there ever be, discrete natural and cultural domains (Latour 1993).

The other distinguishing feature of posthumanist discourse is its rejection of the singular and bounded model of the human subject. Both deconstructive or "anti-ontological" posthumanists and those who propose

\footnotetext{
${ }^{2}$ In spite of the recent explosion in posthumanist scholarship, I have chosen to focus almost exclusively on Latour and Haraway because their pioneering efforts and widespread influence in the humanities and social sciences have, in many ways, made them ambassadors of the paradigm. For more on the reception of Latour and Haraway, see Saldanha (2003) and Castree (2009).
} 
alternative ontologies have been preoccupied with the many exclusions — and with the violence-performed in the name of the human. However, while the former have often been content with decentering the subject and clearing a space for multiple possible subject positions, the latter have gone further, suggesting that humans are not the only source of agency. In their view, traditional explanations of human-nonhuman interaction have placed too much stress on consciousness and cognition at the expense of the active participation of nonhumans. An examination of terrestrial relations must instead consider the various ways in which other-than-human agents, from the geological to the parasitical, play a crucial role in the enactment of social life (Castree et al. 2004; Lorimer 2009).

\section{Expanding the collective}

ANT's architects have been notoriously agnostic about everything from the theory's name (Latour 2005) to whether it can even be described as a "theory" (Law 1994). This reveals a deconstructive streak. At the same time, they have dedicated themselves to the more "positive" task of foregrounding the liveliness of the more-than-human world. If ANT is not free of presumptions about how the world works, its advantage is that, with respect to what Latour calls the "sociology of the social", it makes fewer of them. Whereas conventional sociologies take the "social" to be a stable substance, a context in which supposedly non-social activities take place, ANT considers the social itself as part of what needs to be explained. One cannot take as given distinctions between classes of possible actors whether natural/social, micro/macro or economic/cultural. Nor can one assume that there is a pre-assembled order to which actors can be said, or made, to conform (this is the source, as we shall see, of Latour's more serious objection to critical sociology). Instead, ANT proposes that we approach all of these things (actors, order, the social, and so on) as relational effects, applying a methodological principle of "generalized symmetry" (Callon 1986; Law 2009). ANT's goal, in other words, is to trace the means by which society-or the "collective" in Latour's preferred terminology - is assembled, through the relations between different actors and in such a way that it does not unduly privilege a particular locus of action.

Central to this goal, and the reason for the theory's name, is an understanding of agency as a collective achievement of networks of heterogeneous "actants"—neither human nor object but "hybrid." Like the other phenomena ANT seeks to trace, networks are not an immutable architecture, something that exists on a plane "above" or "below" the practices being described. They are themselves relational effects. This does not mean that immutability is not possible within networks but that such a condition can only come to pass by virtue of the work or the "translations" of various actors/actants. Ultimately, it is stability and not instability which needs to be explained. Against the sociology of the social, an approach in which order is the background in front of which changes can be understood, ANT sees contingency, uncertainty and fluidity as the rule (Latour 2005: 35). In this sense, and because it can account for the relations between sundry entities in a way that other frameworks cannot, ANT is better able to capture the messiness and impurity of social reality.

The strength of ANT vis-à-vis socionatural relations has led more and more scholars to it as a means, and in some cases a cure-all, through which to "green" their disciplines (Saldanha 2003). The corresponding turn away from Marxian approaches has been a source of concern since, for many commentators (e.g. Castree 2002; Gareau 2005; Ivakhiv 2002), ANT's advantages end in the analytical domain. Others have put it more strongly, arguing that ANT might be "politically useless" (Rudy 2005: 119) or even that it is complicit in the imperial practices it claims simply to describe (Fine 2005; Lee and Brown 1994). As I will explain shortly, there is reason to be suspicious both of ANT and the tendency toward a wholesale dismissal of its less fashionable competitors. But what these assessments often miss are the important normative and, indeed, political contributions of ANT. It is clear, particularly in Latour's "how-to manual", Reassembling the social (2005), that ANT is propelled by a radical egalitarianism. We can see this in the language he uses and the concern he shows for both nonhuman and "superhuman" agency. In the first case, the importance of assigning a performative role to nonhumans is consistently grounded in appeals that highlight their exclusion under previous regimes of the social. We are persuaded to expand our conception of agency beyond the human on the basis of the idea that microbes, machines, baboons and the like have heretofore been denied appropriate representation. "Like humble servants, [nonhumans] live on the margins of the social doing most 
of the work but never allowed to be represented as such" (Latour 2005: 73). Where they are admitted, they are not afforded any creativity but are treated as "the hapless bearers of symbolic projection" (ibid: 10). The incorporation of nonhumans is, therefore, not only a matter of correcting the ontological incompleteness of traditional sociological accounts but also a way to redress an historical injustice.

A similar motivation underpins Latour's attitude to religion or, more generally, to modes of being-inthe-world which collide with those of the social scientist. The problem with conventional social theory, he explains, is that it claims to be able to abstain from metaphysics entirely. The truth is that avoiding metaphysics is just not possible, and ignoring this only disguises the worldview of the analyst. More worrying still are the "vampirical" moves which this posture enables. In other words, because there is no room in the sociology of the social for gods, spirits, ancestors and other "supernatural" beings, these presences are routinely consigned to the status of mere "social facts"— or worse, in the case of critical sociology, to "typical cases" of "false consciousness" (ibid: 48). The tragedy in this is that it empties the world of entities which do not conform to the metaphysical framework and the political agenda of the analyst. It holds up as superior the investigator's version of the invisible even, and in fact especially, when this version is expressly denied by the (human) objects of investigation themselves. In Latour's words, critical sociology

...is the only discipline that finds itself scientific when it not only ignores data and replaces it with uncontroversial data from already assembled social forces, but also when it takes the indignant reactions of those who are thus 'explained' as what proves the unbearable truth of the critics' interpretations (ibid: 49-50).

By following the actors rather than disciplining them, and by taking the "world-making" activities of people seriously, ANT hopes to protect them from the arrogance of sociologists who take them to be so many victims of delusion.

What these two cases demonstrate is that Latour's version of ANT is a democratic and even critical project-critical, that is, of the blindness and hypocrisy of orthodox sociology and, in spite of its name, critical sociology. Both are charged with marginalizing nonhumans and with dismissing the ways in which actors themselves define and order the social world. Critical sociology is especially worthy of our suspicion, according to Latour, as it not only limits itself to the social but also takes on the charge of "liberating" those it sees, at best, as "informants." Critical sociologists are not interested in the metaphysical innovations of "ordinary" actors and are surely not moved by them. They may claim to be interested, above all, in emancipation but this is only if it can be achieved on their own terms. ANT, by contrast, is driven by a desire to break down these barriers, by a refusal to decide in advance to whom moral and political consideration ought to be extended. Because any circumscribed collective, we are reminded, "is always a dangerous artifice." To avoid the risk of "seeing the collective only from within" and of "reaching agreement at the expense of certain entities that would be definitely excluded from the collective and considered as mere means", the door must remain forever open (Latour 2004a: 157-158).

The irony here, of course, is that ANT is hardly an "open house." It maintains, like the sociologists of the social that Latour critiques, a commitment to the "unquestionable existence of [certain] boundaries" (Latour 2005: 28), chief among them that between the "travel guide" (i.e., the method) and the "territory" (i.e., the object) upon which the guide is merely superimposed (ibid: 17). Put differently, for ANT, it is essential to preserve a distinction between what is a property of things and what is a property of humans interpreting things, even if this involves removing the framework of networks from contamination by the social reality it seeks to describe. Latour is unambiguous about this: "Network is a concept, not a thing out there. It is a tool to help describe something, not what is being described" (ibid: 131). Insofar as its proponents place it above the fray, ANT itself circumscribes the collective, and against Latour's cautions to the contrary. It is unable to account for, and so helps to camouflage, its situatedness, and that of the sciences more generally, as a form of knowledge. There is little consideration for whether or to what extent structures of inequality (e.g., patriarchy, heterosexism, colonialism/imperialism, the international division of labor, speciesism) might be built into ANT's categories and concepts, how they might be, in Haraway's words, "crucial parts of the 'technical 
content' of science" (Haraway 1992: 332). And while he is certainly interested in recovering human and nonhuman voices who have been denied representation, Latour does not ask why some have been marginalized in networks or what is to be done about those who do not leave a "trace" and whose voices cannot, therefore, simply be recovered (Mallavarapu and Prasad 2006; Watson 2011). We might then conclude, after Gayatri Spivak (1988), that the "subaltern cannot speak" through ANT while the EuroAmerican, heterosexual, male scientist can.

In fairness, Latour's unwillingness to confront his participation in the various axes of oppression is less an oversight or a symptom of indifference than a matter of fidelity to ANT's methodological agnosticism. For Latour, power and domination, like the "social" terrain within which these forces are commonly seen to operate, are the effect of a multiplicity of interactions and not something which can be wielded as a preemptive explanation. In addition to masking the material and other "extra-social" ties which help to preserve relations of inequality, quick recourse to "capitalism", "imperialism", or social "inertia" distracts from the difficult, ceaseless work that goes into renewing these inequalities. Likewise, it confuses the categories or scripts used to explain social reality-themselves actants which influence the state of affairs-with the empirical reality itself. This, in turn, evacuates "power" of any explanatory significance and, in the case of critical sociology, reifies the very relations of domination it claims to have an interest in dismantling. The tables are thus turned on critical scholars whose "lust" for powerful explanations exposes, at best, their political impotence (Latour 2005: 85). While this reversal demonstrates once more the radical egalitarianism of Latour's ANT program, it also contains some troubling implications. The essential political problem with resorting to social explanations, we have learned, is that it substitutes the plurality of beings and modes of being with what is assumed to be the truth "behind" them. The antidote Latour offers for this anti-fetishist urge is to return the favor, to push the logic of de-reification further so that it folds back in on critical sociology's own idols. But if critique silences the voices it seeks to liberate, as Latour insists, this alternative-if indeed it is one-displaces the usual objects of critique onto critique itself. The failures of ossified forms of critical practice become the justification, paradoxically, for an end to critique (Noys 2010). In recommending, moreover, that we refuse the categories that enable macro-level analysis, Latour may end up doing more (and less) than immunizing academics against hypostatizing social structures. If ANT theorists and practitioners influence the networks they describe, this threatens instead to contribute to the erosion of the identities — however phantasmic they might be-that motivate action and mobilize solidarities.

This points to what is, to my mind, the fundamental weakness of the actor-network paradigm. Although Latour's form of ANT is motivated by a laudable concern with injustice, he is, in the end, unable to justify this concern from within ANT. Put otherwise, Latour does not provide us with the equipment necessary to explain why one ethical or political position is better than any other-and this includes 1) why we as scholars ought to consider the accounts and agency of peripheral actors and 2) why we ought to assume the project of the political emancipation of nonhumans. Neither proposition can be defended solely on the basis that it offers "a much more scientific way of building the social world" (Latour 2005: 24). The first, moreover, is leveraged by the hierarchical distribution of knowledges and knowledge workers, a notion which Latour adamantly rejects (ibid: 64). Related to this, as I have already indicated, because of Latour's "anti-antifetishism" — and, in particular, his unwillingness to "impose a priori some spurious asymmetry among human intentional action and a material world of causal relations"-ANT dispenses with the critical tools we already have (ibid: 76). For all his concern to dissolve the boundary between human and nonhuman, to "flatten" the social world as it were, it is precisely this border and other asymmetries such as that between oppressors and oppressed that give ANT its critical purchase. Without these differences, there is no reason to eliminate them, no political project to take on. The existence of boundaries and hierarchies is what makes possible a demand to bring into the collective all those who have heretofore been excluded from it.

That ANT must (and does) draw upon philosophical resources from "outside" would not be a problem if not for Latour's overstatement of the paradigm's potential. Not only does ANT offer improvements in certain respects, as he writes in Reassembling the social it represents a new and more advanced "stage" in the historical progression of sociological thinking. It is "a major shift in our mental apparatus" comparable to the arrival of relativity theory in physics (ibid: 12). Like relativity theory, ANT is capable of rendering different frames of reference commensurable. This is not to say that "pre-relativist" approaches (i.e., the sociology of 
the social and critical sociology) no longer have any use but that, unlike them, ANT is able to discern patterns at an "increased level of abstraction" (ibid: 23). ANT offers an Archimedean point from which to make fungible the multiple metaphysics of the actors it studies. It is, Latour avers, a general ontology "through which the multiplicity of reality—-metaphysics—can be distinguished from its progressive unification" (ibid: 120). Here, I think it is fair to say, Latour is guilty of the very sin he sees critical sociologists committing, that of replacing other forms of world-making with his own. As a meta-theory or "grand narrative" which can explain (or simply describe) everything, ANT closes the door on other ways of being-in-the-world, albeit at a higher plane of understanding (Lee and Brown 1994).

A final objection to ANT, which may come as a surprise to those inclined to agree with its humanist critics, is that it pays comparatively little attention to some nonhumans. It is not, in particular, very useful for grappling with the liminal position of nonhuman animals-neither human nor object, in some cases sentient, in some cases not. Again, this is less a casualty of Latour's disinterest in human-animal relations and more about a programmatic refusal to identify a stable "who" of action and, more generally, to settle the matter of how we are to understand the dividing line(s) between various kinds of beings. But it is nonetheless a casualty. Choosing to view subjects as the temporary consequence of a "swarm" of other entities rather than as meaningful wholes may bring humans down a notch but it also dissolves ethically and politically crucial distinctions between nonhumans. Moreover, insofar as ANT diminishes the importance of subjectivity, intentionality, consciousness, reason and all of the other weapons with which humans have maintained their distance from and superiority over the nonhuman world, it also erodes the foundations for tackling questions of responsibility. It is difficult to see how a robust consideration of our obligations to animals or humans is served by such a strategy. This is unavoidably a human problem and one that cannot but engage with one or more of these categories. From this vantage point, ANT proves to be both too posthumanist and too anthropocentric at the same time-in its denial of the autonomy of human and nonhuman individuals and its lack of attunement to "the question of the animal."

Many of ANT's defects are the consequence of its residual adherence to the "modernizing front." This, at least, is Latour's assessment in his latest book and arguably his magnum opus, An inquiry into modes of existence, or AIME (Latour 2013). While the project of modernization is characterized by the expectation that science/facts can and will eventually be kept separate from politics/values, and that this requires the subtraction of past and present rationalities which interrupt this movement, AIME's interest is to create more space for other values - to "ecologize" rather than modernize (Latour 2013: 8). On the one hand, this involves provincializing the values—and the ontology—of "the Moderns", a difficult assignment in light of their shifting geometry and the gap between their self-understandings and their practices. In a more positive vein, and because it is above all a diplomatic enterprise, AIME seeks to (re)describe these values in terms which coincide with what actors understand about themselves, in practice if not in theory. As Latour states repeatedly throughout the work, the goal is "to speak well in the agora to those who are concerned with what one is saying about them" (ibid: 355). To judge whether or not this is actually the case, Latour's inventory of modern(ist) values is left open to reformulation in the form of a "digital environment"—an online agora, as it were- through which others can participate in the inquiry. The merit of the study depends upon whether the experiences accounted for can be shared, something which cannot be assumed at the outset.

And here is where the contrast between AIME's method and that of its precursor is sharpest: though ANT allows researchers to study the connections between entities without obeying their arbitrary division into domains, it does so, Latour now admits, by imposing a singular metalanguage on all of them. This means that it is unable to register what distinguishes beings or ways of being or to acknowledge the particularity and the relative advantage of the analyst. As Latour puts it, "A tool in the war against the distinction between force and reason, [ANT] risked succumbing in turn to the unification of all associations under the sole reign of the number of links established by those who have, as it were, 'succeeded"' (ibid: 64). Despite its divergence from ANT, AIME continues to rely on the tracing of associations. Only now, Networks are but one of the multiple "modes of existence" through which a given situation can be understood. Together with Prepositions, which define the truth regime and the order of beings proper to each mode, Networks provide the means for accessing the other modes. In this sense, the "crossing" between Networks and Prepositions is primary. It makes it possible to examine the relationships and resemblances across modes without sublating 
what is unique about each of them. A meta-theoretical apparatus is still deployed here but it is a provisional one, like Latour's list of modes itself, and necessary only to the extent that it can prevent one mode from crushing any of the others. By renovating network analysis like this, and turning the anthropological gaze back on those who have considered themselves the standard of comparison, Latour's hope is that we can begin to weigh worlds more equitably and, in so doing, create the conditions of possibility for building, and not simply assuming, a common world.

If, in AIME, scientific knowledges and Latour's framework for analyzing the world(s) are returned to the fray, this does not entail a collapsing of the distinction between map and territory, between "knowing mind" and "known object." Rather, both signs and things, the world and statements about it, are endowed with materiality. They are no longer seen as opposites but as "the progressive result of the extension of chains of reference" (ibid: 80). It is through the work of Reference, another of Latour's modes of existence, that the world and its "existents" are articulated, and in a way that makes visible the local and metaphysical quality of this operation. Existents are not independent from chains of reference (there are no "things in themselves") but neither are they dependent on knowledge for their existence. Like chains of reference, "existents themselves are also going somewhere, but elsewhere, at a different pace, with a different rhythm and an entirely different demeanor" (ibid: 84). The subject-object dualism is displaced here -but it is not replaced, since there are more than two modes of existence in Latour's inventory-by the "risky" crossing between Reference and Reproduction. Reproduction applies to the biotic and the abiotic but also, Latour writes somewhat cryptically, to all sorts of existents (e.g., languages, ideas, institutions) which "insist on existing without any possibility of return" (ibid: 101). The benefit of this "change of correspondence" is that it neither forfeits the boundary between "the real" and the diversity of worldly knowledge forms, which would open it up to the charge of relativism, nor does it reduce ontological disagreements to nothing more than multiple representations of a single world, which would rarefy the modes of existence. It does, however, spell an end to the idea-to which, as we have seen, ANT is still tied-that certain forms of knowledge correspond more easily and more directly with the reality they purport to describe. Instead, each mode of existence is granted "equal access to the real" (ibid: 146). In this way, AIME can take seriously both lived experience and the "material" world.

Latour's new research program is remarkably reflexive; much of it is, as noted, open to review and reconstruction by its co-investigators. This offers a certain immunity from criticism until, so to speak, all the ballots have been cast. But as Latour submits in his concluding chapter, the various tests to which his inquiry must be prepared to respond are united by an overriding interest: to understand whether it prepares us better than its modernizing forerunners for "the diplomacy to come" (ibid: 479). With this in mind, a few problems enter into view. AIME's design is, to be sure, more nuanced and attentive to differences than ANT. And this includes differences between nonhumans who are, this time around, divided into "lines of force" and "lineages." Lineages, or living beings, are recognized as more complex, sensitive, and inventive than lines of force, which is not to say that it would be fair to describe the latter as "inert" (ibid: 100-101). And yet, this greater openness to difference does not always make a difference to the framework itself. To the degree that it depends upon "speaking well" and respecting the plurality of "ways of speaking", for example, Latour's agora is structured in advance to privilege certain kinds of living beings. Though we are urged to be wary of the hasty aggregation of entities under the category of the subject, due to the illusions of mastery that this operation fosters, it is nonetheless clear "who" qualifies as a subject of experience and, in turn, a legitimate participant in the coming "planetary negotiation." The commitment to uncertainty about the locus of action and the boundaries between beings - a pillar of ANT's egalitarian politics — is here betrayed by a vision of the common world in which speaking subjects exercise a gatekeeping function. Truly taking nonhuman difference (and sameness) seriously means broadening the diplomatic scene to include the multiform experiences of other sentient beings. For this, as Jane Bennett (2010: 108) writes, we need "new procedures, technologies, and regimes of perception that enable us to consult nonhumans more closely, or to listen and respond more carefully to their outbreaks, objections, testimonies, and propositions." In its initial form at least, AIME does not deliver these.

The defining exercise of the Political, yet another mode of existence, is the expansion and renewal of the circle of beings in the face of the cries of those who have not (yet) been represented. The task is 
impossible, Latour explains, since there will always be a "they" left outside by any formation of a "we." Still, we must trace the circle anyway (Latour 2013: 338). In this insistence, Latour reveals an abiding interest in correcting past injustices but, also, an implicit acknowledgement that AIME will no doubt fail to do so. At the same time, accepting the inevitability of exclusions does little to further an understanding of the various processes and logics of exclusion. Nor does it help us to address who is responsible, and in what ways, for these elisions. Here then, as in ANT, Latour's preference for the work of (re)construction comes at the cost of attending carefully to the "victims" of his and other regimes of representation. It may even undermine AIME's diplomatic intent, if we understand diplomacy not only as an effort to make room for entities and values that have previously been denied effective representation but as the charge of bearing witness to those who are either incapable or unwilling to protest their marginalization (Stengers 2005).

From this perspective, and to explain why we must trace the circle-why we ought to be interested in doing justice to a diversity of beings and modes of being-it might have been prudent to recognize the importance of some rather conventional tools, especially those with a critical edge. Yet again, however, we are told that that it is not advisable to seek refuge in the "poisonous resources of anti-fetishism" (Latour 2013: 171). Decades ago, critical thought played an essential role in overturning outmoded institutions. But today, because of its tendency to deny multiple realities and, accordingly, its disrespect for those it claims to want to set free, it no longer serves a progressive function and must be renounced (ibid: 261). This prescription is puzzling since, as I have shown, Latour's ANT is far from a complete rejection of critical thought. The point is not to avoid critique but to radicalize it, to give it a new direction. Even with its positive thrust, AIME follows in this path; it is similarly concerned to uncover contradictions between theory and practice and to free the Moderns from their misguided obligation to undeceive. In an article for the journal Critical Inquiry, Latour is more transparent about his lasting allegiance to critical theory-or at least his ambivalence about it. What the present requires is a renewal of the critical spirit, which is to say, the problem is that "critique has not been critical enough" (Latour 2004b: 232). On this matter, it seems, theory and practice are as out of sync for Latour as for his Moderns. "Critique" plays the role of bogeyman and its champions are judged as uniquely incapable of self-criticism, a gesture which does little to "speak well" to many of Latour's academic interlocutors. We are forced into a choice: either critique or diplomacy, a modernizing past or an ecologizing future.

\section{Another posthumanism}

Latour's work may be the most popular theoretical resource for social scientists seeking to bridge the divide between the material and the societal but it is not, of course, the only one available. The work of Haraway, to which we will now turn, is similarly concerned to emphasize the cross-contamination of the two spheres. For Haraway, much as for Latour, the dualisms through which we have come to understand the world and the beings in it are relational effects; they must be distinguished from what they describe. Likewise, there are, in her view, no essential features of the entities which populate the world, nor any original, final or singular sources of action. Beings do not exist prior to their intermingling; "...all that is, is the fruit of becoming with" (Haraway 2008: 17). Haraway's eclectic corpus does not provide her readers with, and in fact actively avoids, a systematic alternative to the bicameral approach she hopes we can eventually overcome. This is one reason why her "nonhumanism" (ibid: 92), as she prefers to call it, has not had the ready-to-hand quality of ANT. Theory is better when "diminutive" (Haraway 1992: 295). This way, it remains sensitive to the fact that it does not offer a "view from nowhere", and that assuming otherwise means falsely universalizing a particular cultural, historical or bodily experience-a problem for Latour which, as we have seen, persists in AIME.

Since a programmatic style is not for her an option, Haraway's solution, if we can call it that, is to generate new and more modest conceptual tools and metaphors - the most famous of which is undoubtedly the "cyborg"—and to tell stories in an altogether different way, in the hopes that this might produce more livable "other worlds" (Haraway 2008: 41). Crucially, the promise of these other worlds depends on confronting - and critiquing - the myriad ways in which forms of hierarchy are embedded within our modes of knowing about the worlds we already have, however scientific they might be. One cannot, as she charges 
Latour with doing, simply dismiss patriarchy, capitalism and imperialism as "old 'social' ghosts" that stand in the way of explaining what is actually happening, that is, not without reproducing these structures of domination (Haraway 1992: 332n). Doing social theory in a way that is attentive to the macro-political and equally aware of the partiality and contingency of all explanations is extremely difficult but the only way for scholars to take responsibility for the knowledge they produce. Scholars must, in Haraway's words, "negotiate the very fine line between appropriation of another's (never innocent) experience and the delicate construction of the just-barely-possible affinities, the just-barely-possible connections that might actually make a difference in local and global histories" (Haraway 1991: 113).

Beyond her cautious but clear commitment to critical thought, Haraway's project has one other essential advantage over Latour's: it understands the need to take seriously that which distinguishes nonhuman animals from the rest of the living. In other words, it does a much better job of acknowledging differencesbetween and within the categories of the human and nonhuman-and of marking the significance of specific human-animal relations. This is the overarching theme, if there is one, of the Companion species manifesto (2003) and the more recent When species meet (2008). Both take as their point of departure the relationship between Haraway and her dog Cayenne on the way to exploring how this singular cross-species encounter might inform better and more inter-subjective ways of relating. A key obstacle to this possible future, according to Haraway is "human exceptionalism" or the presumption that "humanity alone is not [part of] a spatial and temporal web of interspecies dependencies" (Haraway 2008: 11). The attitude is betrayed, for example, in the peculiar penchant humans have for telling the story of evolution, with its subplot involving dog-human relations, as "man making himself yet again in the Greatest Story Ever Told" (Haraway 2003: 5).

But it is not so easy to disentangle dogs and humans from each other in such a way as to describe their changes as "Nature" and our changes as "Culture." Better to accept the "metaplasmic, remodeled versions which give dogs and other species the first moves in domestication and then choreograph an unending dance of distributed and heterogeneous agencies" (ibid: 28). These stories of co-evolution, which Haraway elsewhere calls "ontological choreographies", have a better chance of being true, in her view. They also have a useful lesson to teach us: that dogs and people are "companion species" whose destinies are intimately intertwined. This does not imply that we are one but, rather, that we are significantly other to each other. The trick to getting along better is to keep in mind that "all ethical relation, within or between species, is knit from the silk-strong thread of ongoing alertness to otherness-in-relation" (ibid: 50). Whereas the central task for Latour is to (re)unite humans and nonhumans, to assemble all beings under a common, if radically reconfigured, constitution, Haraway's goal is to resist such an assimilative strategy. The point is that we become more alert to the ways in which nonhuman animals are not like us. Dogs are not just furry children and thinking this demeans both children and dogs as well as setting them up to be harmed or even killed (ibid: 37). Dogs, and other nonhuman animals, are certainly related to us but these connections are partial and they happen across irreducible differences.

Haraway's formulation is undeniably more textured and respectful of the specificity of nonhuman life and animal-human interactions than that of Latour. But, as with him, differences do not always make a difference for Haraway. To put it another way, a concern for the significant otherness of humans and animals does not, in her work, translate into a basis for challenging the asymmetries between humans and their others. Indeed, it often has precisely the opposite effect, that of naturalizing relations of power between humans and other animals. ${ }^{3}$ Consider the idea that unequal or instrumental uses of animals by humans, including those which cause pain and killing, are "not the definition of unfreedom or violation", as opposed to the "objectifications and oppressions of sexism, colonialism, and racism" which definitely are (Haraway 2008: 74-75). Or that, even in extreme instances of animal use such as lab experiments or factory farming, animals experience "many degrees of freedom" from "an inability of experiments to work if animals and other organisms do not cooperate" to a "refusal to live" in the case of chickens and pigs slaughtered for their meat (ibid: 72-73). If, as Haraway sees it, "animals are everywhere full partners in worlding, in becoming with" (ibid: 301) and, more surprisingly, "humans are not uniquely obligated to and gifted with responsibility" (ibid:

\footnotetext{
${ }^{3}$ For an extended critique of Haraway's positions on human-animal relations, see Weisberg (2009).
} 
71), then how — and with what leverage — can we protest the institutions and practices through which animals are everywhere subjected to systematic violence? What reason is there to be concerned about animal mistreatment or, for that matter, to consider it mistreatment at all? Once again, it is difficult to see how responsibility, in its ethico-political connotation and not simply a causal or ontological one, is not exclusively a human burden. It is ours to bear alone. By diminishing important differences between humans and nonhumans, Haraway threatens to rob us of the means by which we confront the exploitation of human and nonhuman animals alike. Her thinking is, in this sense and like Latour's, too posthumanist. On the other hand, Haraway's failure to apply the same concern, if not necessarily the same criteria, to animal and human suffering highlights her firm commitment to the same human exceptionalism that she elsewhere insists is a barrier to a more livable world. In this respect, to return to Latour, she closes the door on a more expansive conception of the collective. The bottom line here is that while Haraway's posthumanism improves upon ANT in a number of ways, it is insufficient for making-and providing a foundation for-claims for justice on behalf of human and nonhuman animals. We cannot find, in Haraway's oeuvre any more than in Latour's, a panacea for the challenges that face political ecology or any of the social sciences.

\section{A call for anxiety}

In an appeal to left-leaning geographers who have discarded political economy approaches in favor of ANT-informed ones, Noel Castree (2002) concedes that the former approaches have, in their more orthodox forms, become more and more inadequate for dealing with "the question of nature." But Marxism is hardly fit for the dustbin of history, he adds, and by refusing to avail themselves of the critical resources that it offers, or to concede that ANT has something to learn from Marxian work, researchers throw out the proverbial baby with the bathwater. What is required is a compromise-a combination of a weak version of ANT and a relational eco-Marxism which, in effect, "splits the difference" between them (ibid: 111). Some have proposed, in complimentary fashion, that ANT should be brought into "synthesis" with Marxist theory. Scholars would then be encouraged to consider more carefully the role played by all actors (Gareau 2005) while remaining attuned to the asymmetries that structure relations between and also within the "social" and the "non-social" (Perkins 2007).

My position here is that efforts to synthesize paradigms should be avoided since, as Haraway and others warn (Chakrabarty 2001; Derrida 2008), this can only come at the expense of important discontinuities. Yet the problem with calls for reconciliation is not, in my view, that they often privilege the human "side" of the equation and so deprive network analysis of its key methodological and normative strength: its "profound uncertainty" about the composition of the social (cf. Holifield 2009). As I have argued in the case of AIME, Latour's approach is not immune to the charge of resolving that matter of "who" exercises agency and how it is, or ought to be, distributed. The social may not be limited to the human but membership in the collective nonetheless depends upon the mediation of beings capable of speech. ${ }^{4}$ Performative contradictions such as this are a condition of much posthumanist thought, according to Jane Bennett. Attempts to cultivate a sensitivity to the more-than-human are prone to "falling back" on the use of humanist tactics-to being led down "the anthropocentric garden path" (Bennett 2010: 120). But the answer here is not for us to try harder to expunge the residue of the human, the social or the modern or, alternatively, to abandon the posthumanist impulse. Nor does it mean that it would be best to "keep the two separate" (Holifield 2009: 639). Since no theoretical frame is self-sufficient or all-encompassing, and each can be useful to reveal what the others elide, it might be better to sustain a productive tension between diplomacy and critique, science and politics, Marxism and network analysis, situated and systematic knowledges, modernism and postmodernism, and most importantly for our purposes here, humanism and posthumanism. I have shown that posthumanisms are indispensable for overcoming the tendency on the part of the human sciences to ignore the active participation of nonhumans. But they are also inadequate when it comes to addressing conditions of injustice. Whatever

\footnotetext{
${ }^{4}$ Through its emphasis on following the "accounts" of actors and "feeding off controversies," ANT also awards (certain) humans with an "executive" function. In this sense, like AIME, the question of which beings matter is foreclosed and against Latour's concern to do otherwise.
} 
their limitations, we have yet to find better tools for doing this than the old-fashioned humanist ones we already have. Subjectivity, intentionality, the sovereign individual, human-centered conceptions of responsibility, even the boundary between humans and nonhumans — all of these we can neither live with nor without.

As I see it, then, in order to retain the essential insights in posthumanist work and to avoid the perils associated with its uncritical appropriation_-both of which I have tried to outline here-political ecologists and other engaged academics should avoid surrendering to the "blackmail" of choosing one theoretical practice or methodology over another. Neither should they, for the reasons explored above, seek to resolve and thus erase differences, even if only at a higher or meta-theoretical level of abstraction. The challenge is to work through these differences, to negotiate the anxieties and repressions which attend our theoretical histories and competing worldviews, and to keep in relation the constitutive dualisms of "Western" thinking which are essential to "our" emancipatory aspirations. Here we might find useful the Gramscian idea of the mutual implication or co-production of superstructure and structure, nature and society, theory and practice. Antonio Gramsci (1971: 366) understood that one could not neatly distinguish the ways we represent the world and how we live in it. Culture may be influenced by the material conditions in which we find ourselves but it also, in dialectical fashion, modifies and makes possible the overcoming of those conditions.

If this idea has found a foothold in political ecology (Goldman, Nadasdy and Turner 2011; Smith 1984; Swyngedouw 1999), it might be kept in tension with another equally instructive one, which has not. For Theodor Adorno and Max Horkheimer, the pre-eminent figures of the so-called Frankfurt School, the operation of the dialectic was not characterized by its ability to reconcile the "poles" of a given contradiction under some higher unity_a notion to which Gramsci remained wedded—but by its relentless movement. Put differently, the point of dialectical thinking was not, in their understanding, to find a way to discipline, contain, or move beyond particularity but to highlight and, in this way, learn from our repeated failure to do so. For them, in Martin Jay's description, "negation rather than the premature search for resolutions was the real refuge of truth" (Jay 1973: 263). The negative dialectics of Adorno and Horkheimer offer us a way to think in two registers-difference and sameness, being and becoming-at the same time. They are also helpful for fending off a troubling tendency in both Marxist and posthumanist work, namely the drive to subsume all to a single and ultimately false universal framework. And perhaps most importantly, what Adorno and Horkheimer teach us is that, whatever the urgency of overcoming the border between subject and object, human and more-than-human —and the promise that posthumanisms will do just that-a critical political ecology demands otherwise. It must be willing to operate in a permanent state of suspended judgment and to refuse the temptation to settle, once and for all, the question of where truth lies.

\section{References}

Bennett, J. 2010. Vibrant matter: a political ecology of things. Durham, NC: Duke University Press.

Braun, B. and N. Castree (eds.). 1998. Remaking reality: nature at the millennium. London: Routledge.

Braun, B. and N. Castree (eds.). 2001. Social nature: theory, practice, politics. Oxford: Blackwell.

Callon, M. 1986. Some elements of a sociology of translation: domestication of the scallops and the fishermen of St. Brieuc Bay. In J. Law (ed.) Power, action and belief: a new sociology of knowledge. London: Routledge.

Castree, N. 2002. False antitheses? Marxism, nature and actor-networks. Antipode 34(1): 111-146.

Castree, N. 2009. Living in a companioned world. Science as Culture 18(1): 115-120.

Castree, N., C. Nash, N. Badmington, B. Braun, J. Murdoch, and S. Whatmore. 2004. Mapping posthumanism: an exchange. Environment and Planning A 36: 1341-1363.

Chakrabarty, D. 2000. Provincializing Europe: postcolonial thought and historical difference. Princeton: Princeton University Press.

Derrida, J. 2008. The animal that therefore I am (more to follow). In M. Mallet (ed.) The animal that therefore I am. New York: Fordham University Press

Fine, B. 2005. From actor-network theory to political economy. Capitalism, Nature, Socialism 16(4): 91-108. 
Gareau, B.J. 2005. We have never been human: agential nature, ANT, and Marxist political ecology. Capitalism, Nature, Socialism 16(4): 128-140.

Gramsci, A. 1971. Selections from the prison notebooks. Q. Hoare and G.N. Smith (eds.) New York: International Publishers.

Goldman, M., P. Nadasdy and M.D. Turner (eds.) 2011. Knowing nature: conversations at the intersection of political ecology and science studies. Chicago: University of Chicago Press.

Haraway, D. 1991. Simians, cyborgs and women: the reinvention of nature. New York: Routledge.

Haraway, D. 1992. The promise of monsters. In L. Grossberg, C. Nelson and P.A. Treichler (eds.) Cultural studies. New York: Routledge.

Haraway, D. 2003. The companion species manifesto: dogs, people and significant otherness. Chicago: Prickly Paradigm Press.

Haraway, D. 2008. When species meet. Minneapolis: University of Minnesota Press.

Hinchcliffe, S. 2005. Geographies of nature: societies environments ecologies. Sage Publications Ltd.

Holifield, R. 2009. Actor-network theory as a critical approach to environmental justice: a case against synthesis with urban political ecology. Antipode 41(4): 637-658.

Ivakhiv, A. 2002. Toward a multicultural ecology. Organization and Environment 15(4): 389-409.

Jay, M. 1973. The dialectical imagination: a history of the Frankfurt School and the Institute for Social Research, 1923-1950. Berkeley: University of California Press.

Latour, B. 1993. We have never been modern. Cambridge, MA: Harvard University Press.

Latour, B. 2004a. Politics of nature: how to bring the sciences into democracy. Cambridge: Harvard University Press.

Latour, B. 2004b. Why has critique run out of steam? Critical Inquiry 30: 225-248.

Latour, B. 2005. Reassembling the social: an introduction to actor-network-theory. Oxford: Oxford University Press.

Latour, B. 2013. An inquiry into modes of existence: an anthropology of the moderns. Cambridge: Harvard University Press.

Law, J. 1994. Organising modernity. Oxford: Blackwell.

Law, J. 2009. Actor network theory and material semiotics. In B.S. Turner (ed.) The new Blackwell companion to social theory. Oxford: Blackwell.

Lee, N. and S.D. Brown. 1994. Otherness and the actor-network: the undiscovered continent. American Behavioural Scientist 37(6): 772-790.

Lorimer, J. 2009. Posthumanism/post-humanistic geographies. In R. Kitchin and N. Thrift (eds.) International encyclopedia of human geography. Amsterdam: Elsevier.

Mallavarapu, S. and Prasad, A. 2006. Facts, fetishes, and the parliament of things: is there any space for critique? Social Epistemology 20(2): 185-199.

Marx, K. and F. Engels. 1948. The communist manifesto. New York: International Publishers.

Neumann, R.P. 2005. Making political ecology. New York: Oxford University Press.

Noys, B. 2011. The discreet charm of Bruno Latour, or the critique of 'anti-critique.' Paper presented at the Centre for Critical Theory, University of Nottingham, UK.

Perkins, H.A. 2007. Ecologies of actor-networks and (non)social labor within the urban political economies of nature. Geoforum 38: 1152-1162.

Robbins, P. 2012. Political ecology: a critical introduction. Oxford: Wiley-Blackwell.

Rudy, A. 2005. On ANT and relational materialisms. Capitalism, Nature, Socialism 16(4): 109-125.

Saldanha, A. 2003. Actor-network theory and critical sociology. Critical Sociology 29(3): 419-432.

Smith, N. 1984. Uneven development: nature, capital, and the production of space. Oxford: Basil Blackwell. 
Spivak, G. C. 1988. Can the subaltern speak? In C. Nelson and L. Grossberg (eds.) Marxism and the interpretation of culture. Urbana: University of Illinois Press.

Stengers, I. 2005. The cosmopolitical proposal. In B. Latour and P. Weibel (eds) Making things public: atmospheres of democracy. Cambridge MA: MIT Press.

Swyngedouw, E. 1999. Modernity and hybridity: nature, regeneracionismo, and the production of the Spanish waterscape, 1890-1930. Annals of the Association of American Geographers 89(3): 433-465.

Watson, M. 2011. Cosmopolitics and the subaltern: problematizing Latour's idea of the commons. Theory, Culture and Society 28(3): 55-79.

Weisberg, Z. 2009. The broken promises of monsters: Haraway, animals and the humanist legacy. Journal for Critical Animal Studies 7(2): 21-61.

Whatmore, S. 2002. Hybrid geographies: natures cultures spaces. London: Sage Publications Ltd.

White, D. and C. Wilbert (eds.). 2009. Technonatures: environments, technologies, spaces, and places in the twenty-first century. Waterloo: Wilfred Laurier Press.

Wolfe, C. 2010. What is posthumanism? Minneapolis: University of Minnesota Press. 